\title{
Daily application of low magnitude mechanical stimulus inhibits the growth of MDA-MB-231 breast cancer cells in vitro
}

\author{
Melis Olcum ${ }^{1}$ and Engin Ozcivici, ${ }^{1,2^{*}}$
}

\begin{abstract}
Introduction: Mechanical loads can regulate cell proliferation and differentiation at various stages of development and homeostasis. However, the extension of this regulatory effect of mechanical loads on cancer cells is largely unknown. Increased physical compliance is one of the key features of cancer cells, which may hamper the transmission of mechanical loads to these cells within tumor microenvironment. Here we tested whether brief daily application of an external low magnitude mechanical stimulus (LMMS), would impede the growth of MDA-MB-231 aggressive type breast cancer cells in vitro for 3 wks of growth.
\end{abstract}

Methods: The signal was applied in oscillatory form at $90 \mathrm{~Hz}$ and $0.15 \mathrm{~g}$, a regimen that would induce mechanical loads on MDA-MB-231 cells via inertial properties of cells rather than matrix deformations. Experimental cells were exposed to LMMS $15 \mathrm{~min} /$ day, 5 days/week in ambient conditions while control cells were sham loaded. Cell proliferation, viability, cycle, apoptosis, morphology and migration were tested via Trypan Blue dye exclusion, MTT, $\mathrm{Pl}$, Annexin V, Calcein-AM and phalloidin stains and scratch wound assays.

Results: Compared to sham controls, daily application of LMMS reduced the number and viability of cancerous MDA-MB-231 cells significantly after first week in the culture, while non-cancerous MCF10A cells were found to be unaffected. Flow cytomety analyses suggested that the observed decrease for the cancer cells in the LMMS group was due to a cell cycle arrest rather than apoptosis. LMMS further reduced cancer cell circularity and increased cytoskeletal actin in MDA-MB-231 cells.

Conclusion: Combined, results suggest that direct application of mechanical loads negatively regulate the proliferation of aggressive type cancer cells. If confirmed, this non-invasive approach may be integrated to the efforts for the prevention and/or treatment of cancer.

Keywords: Mechanical loading, MDA-MB-231, Physical activity, Breast cancer

\section{Introduction}

Cancer, one of the leading causes of death worldwide, is characterized by the uncontrolled growth of cells that eventually leads to disruption of tissue organization and function [1]. Since no universal treatment is available for cancer other than remedies that kill rapidly dividing cells at the expense of life quality [2-5], prevention strategies are often emphasized for the practice of healthy lifestyle choices such as following a healthy diet, minimizing sun

\footnotetext{
* Correspondence: enginozcivici@iyte.edu.tr

${ }^{1}$ Program in Biotechnology and Bioengineering, Izmir Institute of Technology, Urla, Izmir, Turkey

${ }^{2}$ Department of Mechanical Engineering, Izmir Institute of Technology, Urla, Izmir, Turkey
}

exposure and cessation of substance addictions [6]. One of those healthy choices is to avoid a sedentary lifestyle, and indeed a negative correlation exists between the levels of physical activity and rate of incidence for cancer [7-11]. Increased physical activity is associated with reduced incidence rates of colon, breast, prostate, endometrial and lung cancers $[7,8,12,13]$. Suggested mechanisms for reduced cancer incidence mainly focus on the global effects of exercise on body fat mass, hormonal or immune status [12], but recently interaction of mechanical loads with cancer cells received further attention [14-16].

Mechanical loads are omnipresent in all tissues and they act as an important modulator of cellular machinery 
during an organism's development and homeostasis [17-20]. Cellular decisions such as growth, migration and differentiation are dependent on mechanical loads, and the absence of these loads induces catabolism and malformation in many tissue types. Taking advantage of the regulatory and anabolic potential of mechanical stimuli, daily physical exercise is protective against diseases that are detrimental to tissue integrity [21-23]. Though cellular response to mechanical loads in healthy and diseased tissue types were addressed frequently in the literature [24], how cancerous cells respond to mechanical loads and whether they are exempt from the regulatory effects of mechanical loads is largely unknown.

Many cancer types present themselves with a tumor formation, a structure that is significantly stiffer compared to the surrounding healthy tissue [25]. The stiffness of tumor tissue is governed by the aberrant extracellular matrix deposited by the cancer cells. In contrast, cancer cells that lie within the tumor tissue are more compliant compared to healthy cells as evidenced by single cell mechanical manipulation techniques [26]. Cancer cells can readily utilize their "more compliant state" for an increased efficacy for invasion and migration to distant sites [27]. Other than a small fraction $(<6 \%)$ of cases that are formed as mucinous tumors [28] breast cancer is no exception to stiff extracellular matrix and compliant cell composition [29]. From a mechanical perspective, the composition of an extracellular matrix that is stiffer, and cells that are softer than a healthy tissue suggests that breast cancer cells may also be protected from mechanical loads in a manner that is similar to the event of "stress shielding" seen in orthopedic biomaterial applications $[30,31]$. In a composite structure stiffer elements absorb larger loads compared to compliant elements. Even though cancer cells are known to be responsive to mechanical cues [32,33], if they are protected from global loads within stiffer tumors, then potential regulatory effects of these loads on cancer cells may not be able to potentiate in the first place.

Alternative to external loads that are prescribed to tissues and shared between extracellular matrix and cells, accelerations can be used to generate mechanical loads on the cells based on Newton's $2^{\text {nd }}$ law of motion. In such a system, accelerations would prescribe mechanical loads on every element of the system based on the mass of individual elements. These repeated oscillatory loads need not to be large in magnitude, as healthy tissues and cells can sense and respond to these loads that are at least two orders of magnitude smaller compared to mechanical loads that are associated with regular weight bearing [34-36]. Here we tested whether direct application of low magnitude mechanical stimuli (LMMS) would be detrimental to the proliferation and invasiveness of aggressive type human breast cancer cells.

\section{Materials and methods}

All experiments were conducted in compliance with ethical board of Izmir Institute of Technology. MDAMB-231 (American Type Culture Collection, VA, USA) aggressive type breast cancer cells were used throughout the study. Briefly, cells were cultured using DMEM with high glucose (Thermo Scientific HyClone, UT, USA) supplemented with 1\% Pen/Strep (Biological Industries, Israel) and 10\% FBS (Biological Industries, Israel). MCF10A (American Type Culture Collection, VA, USA) human breast epithelial cells were used as non-cancerous epithelial controls. MCF10A cells were cultured in DMEM:F12 medium (Sigma, MO, USA) supplemented with $20 \mathrm{ng} / \mathrm{ml}$ EGF (Sigma, MO, USA), $0.5 \mathrm{ug} / \mathrm{ml}$ hydrocortisone (Sigma, MO, USA), 100ng/ml choleratoxin (Sigma, MO, USA), $10 \mathrm{ug} / \mathrm{ml}$ insulin (Sigma, MO, USA), 1\% Pen/Strep (Biological Industries, Israel), 5\% donor equine serum and 2 $\mathrm{mM} \mathrm{L}$-glutamine. Cells were kept in $37^{\circ} \mathrm{C}$ and $5 \% \mathrm{CO}_{2}$ except vibratory loading protocol, during which they were exposed to the ambient conditions. For all experiments cells were cultured in 24 well plates (Corning, NY, USA) with a 640 cells $/ \mathrm{mm}^{2}$ density to prevent overpopulation during 3 wks and culture medium was changed every two days. For all experiments, day of plating was considered as day $(-2)$ and cultures were maintained for a range of days, including D1, D3, D5, D9, D12 and D19 (Table 1). At the designated time points, experiments were terminated for further analysis.

Experimental cells were exposed to a daily regimen of mechanical vibration at $90 \mathrm{~Hz}$ and $0.15 \mathrm{~g}(1 \mathrm{~g}=$ Earth's gravitational pull), for $15 \mathrm{~min} /$ day, 5 days/week in ambient conditions, during which control plates were subjected to sham loading. Mechanical signal was provided by a custom-made platform in vertical direction [37], and the mechanical signal quality was continuously controlled with real-time accelerometer (K-Beam, Kistler, Amhers, NY, USA), measurements monitored by Labview 2010 Signal Express (National Instruments, Austin, TX, USA) software.

\begin{tabular}{|c|c|c|c|c|c|c|}
\hline $\mathrm{D}(-1)$ & Do & D1 & D2 & D3 & D4 & D5 \\
\hline$\circ$ & $\circ$ & $X_{1}^{\dagger}$ & $x$ & $X_{1}^{+}$ & $x$ & $X_{1}^{\dagger}$ \\
\hline D6 & D7 & D8 & D9 & D10 & D11 & D12 \\
\hline$\circ$ & ○ & $x$ & $X_{1}^{+}$ & $x$ & $x$ & $x_{1}^{+}$ \\
\hline D13 & D14 & D15 & D16 & D17 & D18 & D19 \\
\hline ○ & $\circ$ & $X$ & $x$ & $x$ & $x$ & $X_{1}^{+}$ \\
\hline
\end{tabular}

X, LMMS/Sham; $\circ$, Rest; $^{\dagger}$, Evaluation.

After plating cells on D(-2), LMMS or sham signal was applied starting from D1 until D19, $15 \mathrm{~min} /$ day, 5 days/week. Cultures were terminated on selected days for the evaluation of cellular indices. 
Number of cells for experimental and control groups were quantified using trypan blue exclusion method, where cells were diluted with $0.4 \%$ trypan blue dye (Gibco, Invitrogen, NY, USA) dye in 1:1 ratio and counted with a Neubauer hemocytometer. Cell viability was analyzed via MTT assay, in which cells were incubated with $0.5 \mathrm{mg} / \mathrm{ml}$ MTT (Amresco LLC, OH, USA) for 4 hours. After the incubation tetrazolium salts were dissolved in DMSO and colorimetric measurements was done at $570 \mathrm{~nm}$ with a background subtraction at $650 \mathrm{~nm}$. Cellular morphology and actin ultrastructure was visualized using phalloidin (Invitrogen, USA) staining followed by analysis of individual cells using Image J software.

Experimental and control groups were subjected to cell cycle analysis based on the DNA content of the cells via propidium iodide (PI) staining. Briefly, cells were collected in $1 \mathrm{x}$ cold PBS solution and then fixed with $\mathrm{EtOH}$. After overnight incubation at $-20^{\circ} \mathrm{C}$, cells were permeabilized with $0.1 \%$ Triton $\mathrm{x}-100$ in PBS and treated with RNase A. Finally, cells were incubated with PI and analyzed with FACS Canto (BD Biosciences, CA, USA) with low flow rate. Based on binomial distribution of PI signal gating and doublet distinction was done according to the area of the signal peaks with a cell cycle analysis software (Modfit LT, Verity Software, USA). Fractions of apoptotic, live and dead cells were quantified using Annexin V - PI (BD Pharmingen, NJ, USA) staining based on the specifications instructed by the provider. Briefly, collected cells were washed twice with PBS then suspended in binding buffer and stained with Annexin V (FITC) and PI dyes. Cells were analyzed with FACS Canto where single stain and unstained cells were used to set event gates. Calcein-AM cell permeant dye (Life Technologies, Oregon, USA) was used to stain MDA-MB-231 cell at days D5, D12 and D19, with $30 \mathrm{~min}$ incubation in the dark, followed by cell detachment and flow cytometry measurements.

Cellular morphology and actin ultrastructure was documented with phalloidin (Alexa Fluor 488, Invitrogen, USA) staining after cellular fixation (4\% paraformaldehyde) and membrane permeabilization ( $0.1 \%$ TritonX in PBS). Images were acquired by fluorescence microscopy (CKX71, Olympus, Japan) and processed with an image processing software (Image J, USA). Scratch closure rates for both groups were quantified using an artificial scratch mark made with the tip of a $200 \mu l$ pipette. Scratches were visualized immediately and after $24 \mathrm{hrs}$ of incubation for both groups using a microscope (CKX41, Olympus, Japan) with image processing software (DP2BSW, Olympus, Tokyo, Japan). The gap between cells was measured from 3 different regions on a single scratch, repeated 10 times within sample. The percent change of average gap length between 0 and $24 \mathrm{hrs}$ was reported as an indicator of gap closure. Mechanical signal was not applied to cells during this 24 hrs period.
All results were reported as mean ( \pm standard deviation). Groups were compared using Student's $t$ test with unequal variance where statistical significance was set at $5 \%$. For all experiments described above, a minimum of 3 replicates were used from both groups, except cell detachment and calcein stains.

\section{Results}

During 19 days of culture a steady increase was observed in sham control MDA-MB-231 cells as measured with Trypan Blue cell counts. At the end of 19 days, on average number of cells increased 108-fold compared to baseline controls (Figure 1a). Number of low magnitude mechanical stimulation (LMMS) treated cells also showed a steady increase during experimental period with an average increase of 92-fold compared to baseline controls. LMMS group had 41\%, 32\% and $18 \%$ (all $\mathrm{p}<0.05$ ) less number of MDA-MB-231 cells at D9, D12 and D19 compared to controls. Similar to Trypan blue readings, cell viability signals of MDA-MB-231 as documented with MTT assays for sham control cells showed a steady increase during the experimental protocol (Figure 1b). At D19 MTT signal showed 25-fold increase compared to baseline controls. Compared to sham controls, LMMS treated cells showed 62\%,18\% and 50\% (all p <0.05) less MTT signal during D5, D9 and D19, respectively. To test if the reduced number of cells in LMMS groups observed because of cellular detachment from culture plate, cells in collected media was counted for both groups using Trypan blue stain (Figure 1c). No significant differences (all $\mathrm{p}>0.1$ ) were detected for number of detached cells in experimental days (Figure 2c). In spite of observed reduction in cell numbers for breast epithelial cancer cells (MDA-MB-231), similar loading with LMMS affected non-cancerous breast epithelial cells (MCF10A) differently (Figure 1d). At the D5, LMMS group had 8\% more MTT activity $(\mathrm{p}<0.01)$ compared to controls. At D12 and D19, MTT activity of MCF10A cells in LMMS group had a non-significant $6 \%$ and $1 \%$ ( $\mathrm{p}=0.20$ and 0.55 , respectively) difference compared to sham controls.

In an effort to explain the reduction of cell numbers and viability in LMMS treated cultures, cell cycle analysis was performed using PI staining. Unfortunately, cultures from both sham control and LMMS groups at D1, D3 and D5 lacked enough number of cells for analysis therefore cultures from D9, D12 and D19 were reported here. At D9, LMMS group had 3\% (0.03) more fraction of cells in $\mathrm{G} 1$ phase while $24 \%(\mathrm{p}=0.03)$ less fraction of cells in G2 phase compared to sham controls (Figure 2a and b). At D12, LMMS group had 18\% $(\mathrm{p}=0.02)$ less fraction of cells in $\mathrm{G} 2$ phase. In contrast to previous time points, LMMS treated cells at D19 had $3 \%(\mathrm{p}=0.05)$ less fraction of cells at $\mathrm{G} 1$, while $27 \%(\mathrm{p}=0.05)$ more fraction cells in G2 compared to 


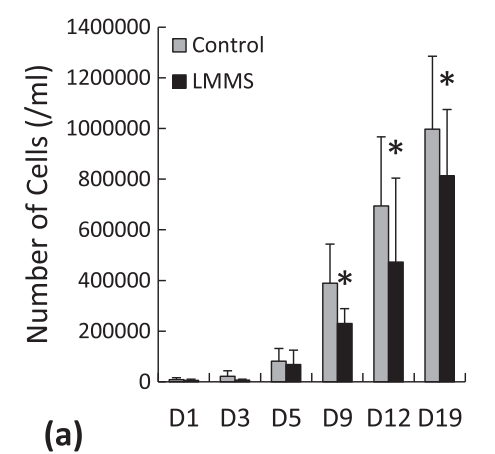

(a)

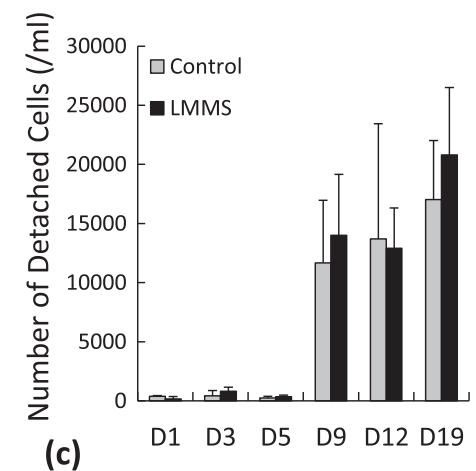

(c)
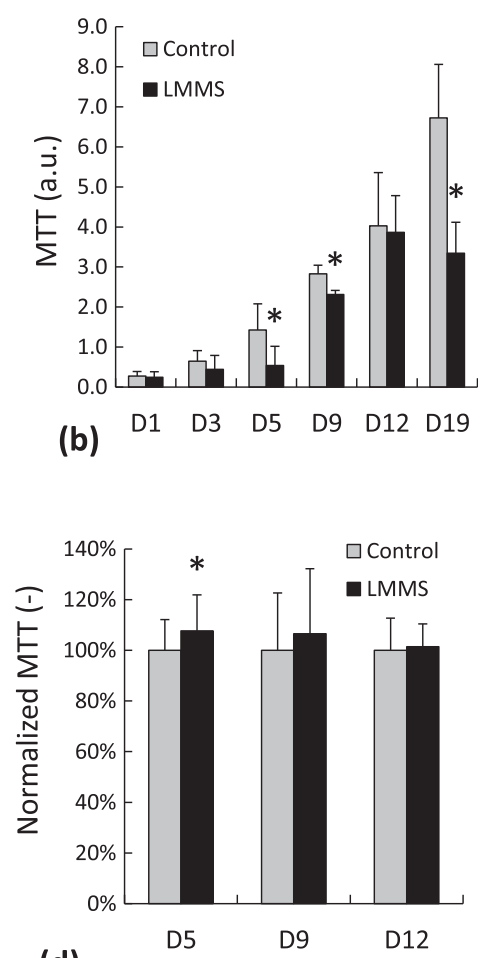

(d)

Figure 1 Cell proliferation measurements of MDA-MB-231 cells for control and LMMS groups assessed with a) Trypan Blue dye exclusion method b) MTT assay. c) Number of MDA-MB-231 cells that were detached from the plastic counted by Trypan Blue stain. d) Cell proliferation of MCF10A cells assessed with MTT assay. (*: $p<0.05$ between LMMS and sham controls).

controls. No significant differences were observed in the fraction of cells that are in S phase between LMMS and controls for the duration of experiment (Figure 2c).

Control and LMMS cells were stained with Annexin V - PI documented for the apoptotic status of experimental cells (Figure 3a). No difference (all p >0.15) in the fraction of apoptotic cells were observed between control and LMMS groups (Figure 3d). Fraction of dead cells in LMMS group was 51\% $(\mathrm{p}<0.01)$ and $28 \%$ $(\mathrm{p}=0.05)$ larger at D12 and D19 compared to controls (Figure 3b). At D12, fraction of live cells had small but a significant reduction $(1.1 \%, \mathrm{p}<0.01)$ compared to control cells (Figure 3c). Furthermore, fraction of live cells at D12 showed a similar reduction $(3 \%, \mathrm{p}=0.02)$ as determined by Calcein-AM staining (Table 2).

The effect of LMMS on the morphology and ultrastructure of MDA-MB-231 cells were determined by fluorescence microscopy (Figure 4a and b). At D1 no significant difference was observed in individual cellular area, cellular circularity and actin content (Figure 4c-e). However at the end of first week cancer cells that received daily LMMS had $32 \%(\mathrm{p}=0.02)$ stronger fluoresce signal with $12 \%(\mathrm{p}=0.04)$ smaller circularity compared to control cells. Migratory potential of MDA-MB-231 increased with the confluence during the experimental protocol as evidenced by $24 \mathrm{hrs}$ scratch closure rates.
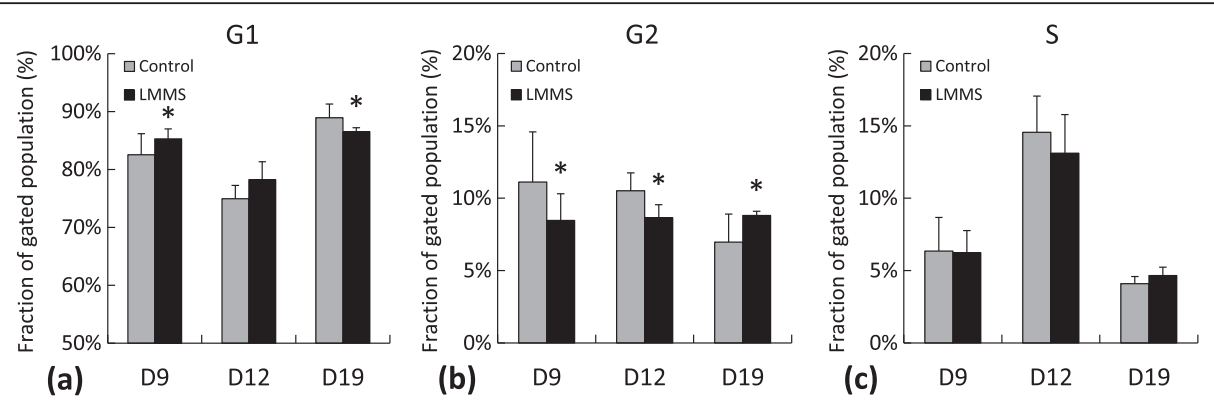

Figure 2 MDA-MB-231 cell cycle assessment showing cell fractions for control and LMMS groups that were in a) G1 phase, b) G2 phase and c) S phase, represented based on experimental days 9, 12 and 19. $\left(^{*}: \mathrm{p}<0.05\right.$ between LMMS and controls). 


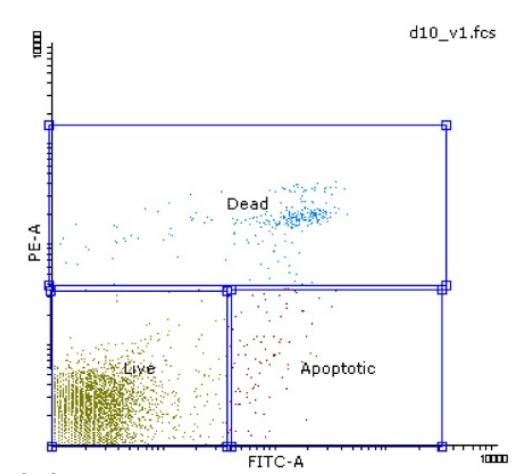

(a)

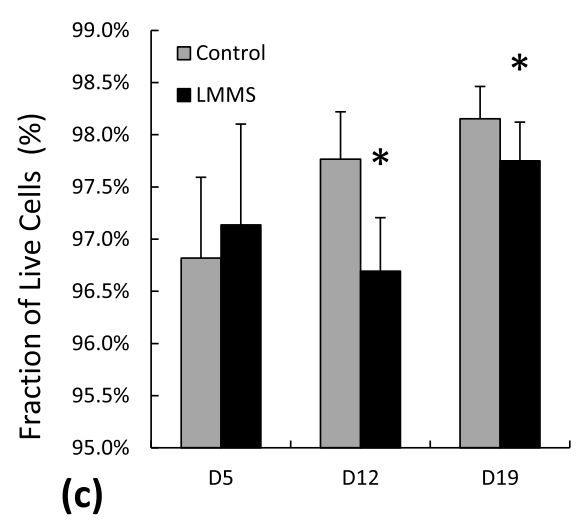

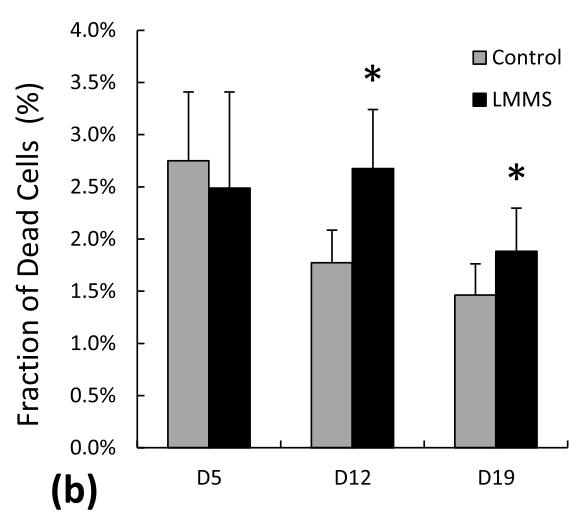

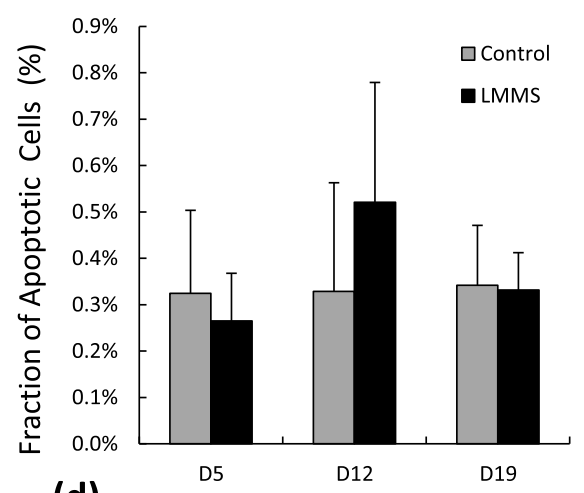

(d)

Figure 3 MDA-MB-231 apoptosis/necrosis assessment with Annexin V - PI stains of control and LMMS groups for different experimental days. a) Representative gates applied for all samples determining dead, live and apoptotic cells. Fractions of $\mathbf{b})$ dead cells (PI+), c) live cells (No stain) and $\mathbf{d}$ ) apoptotic cells (Annexin $\mathrm{V}+, \mathrm{PI}-)$ (*: $\mathrm{p}<0.05$ between LMMS and controls).

However, daily application of LMMS did not affect scratch closure significantly for the time points analyzed (Figure 5).

\section{Discussion}

The ability of low magnitude mechanical signals (LMMS) to interfere with the growth, viability, cell cycle, apoptosis and migration potential of MDA-MB-231 aggressive type breast cancer cell was investigated in vitro for 3 wks duration. MDA-MB-231 cells showed a steady proliferation rate during the extension of the study. Daily application of LMMS reduced number of breast cancer cells at different time points, but did not affect non-cancerous controls. According to the cell cycle analysis, LMMS reduced the fraction of cancer cells that are cycling and arrested them in either G1 or G2 phase. However, LMMS neither interfered with the migratory potential nor induced apoptosis

Table 2 Calcein-AM staining of MDA-MB-231 breast cancer cells at different experimental days

\begin{tabular}{llll}
\hline & D5 & D12 & D19 \\
\hline Control & $93.3 \pm 1.4$ & $92.1 \pm 1.0$ & $92.8 \pm 1.2$ \\
LMMS & $94.7 \pm 1.4$ & $89.5 \pm 1.2^{*}$ & $93.5 \pm 0.6$ \\
\hline
\end{tabular}

$(*: p<0.05)$. in MDA-MB-231 cells. Reported results indicate that the application of LMMS to breast cancer cells may suppress the uncontrolled growth, emphasizing a potential therapeutic benefit against the disease.

Implementation of LMMS for $15 \mathrm{~min} /$ day on MDAMB-231 cells decreased number of cycling cells in shortterm. Colon cancer cells show a similar cell cycle arrest at G1 when exposed to mechanical loads in shear form [38], perhaps signifying a global pattern for the mechanical regulation on cancer cells. Similarly, MCF-7 breast cancer cells cycle more and show increased proliferation during space-flight [39], a condition that induce constant unloading to cells [40]. Further, constant weightlessness on thyroid carcinoma cells is associated with events that increase extracellular matrix formation, metastatic spread with the inhibition of apoptosis [41]. Combined, these data emphasize that future studies should identify the mechanical regulation on the molecular mechanisms of cancer cell cycle and whether brief exposure to daily physical stimulus can impede the growth of other tissue types of cancer.

The stimulus that was investigated here was largely tested in vivo for the anabolic effects in skeletal tissue during and after mechanical unloading [42], for suppression 


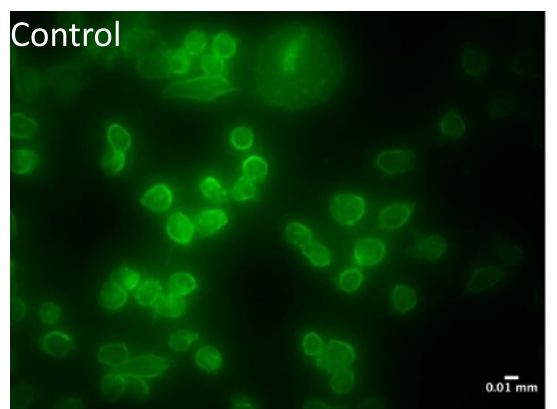

(a)

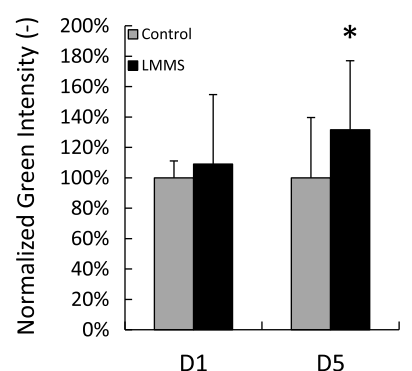

(c)

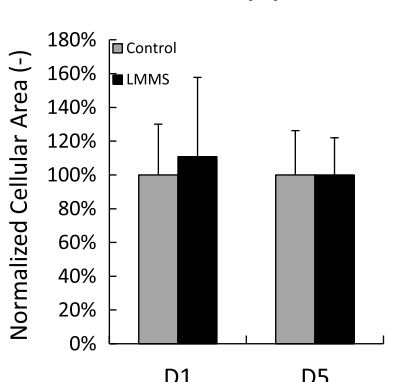

(d)

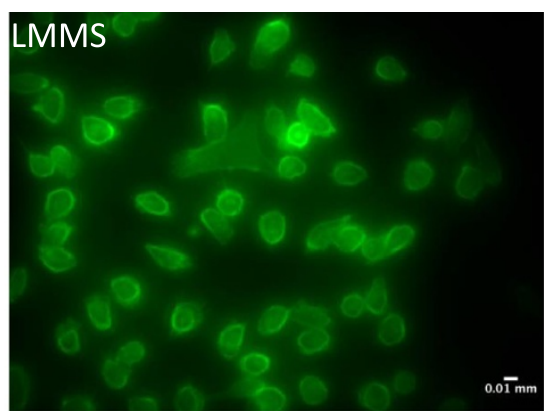

(b)

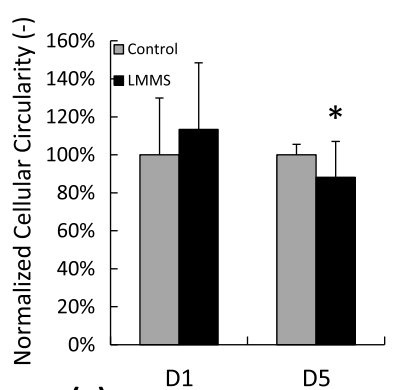

(e)

Figure 4 Phalloidin staining and morphology of MDA-MB-231 cells for control and LMMS groups for experimental days 1 and 5. Representative micrographs from a) control and b) LMMS group. Individual cells were analyzed for $\mathbf{c}$ ) mean green intensity, $\mathbf{d}$ ) cellular area and e) cellular circularity. (*: $p<0.05$ between LMMS and controls).

of adipogenesis in fat pads [43], liver [44] by dietary induced obesity and for normalization of hematological function in bone marrow hampered by obesity [45]. None of those studies reported any adverse effects of LMMS on the tissues studied within. Recently, Pagnotti et al used a similar daily loading regimen on a mouse model of spontaneous granulosa cell ovarian cancer and showed a benefit to skeletal health without compromising the longevity of the organism [46]. These results are important in

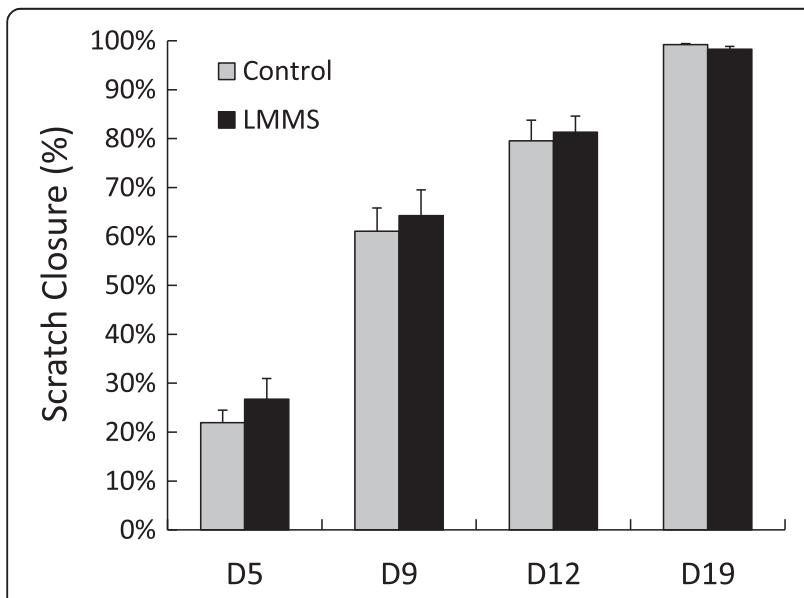

Figure 5 Scratch closure rates (\%) of MDA-MB-231 cells for control and LMMS groups for the duration of 24 hours represented based on experimental days 5, 9, 12 and 19. describing that low magnitude mechanical stimulus is advantageous to tissues that are threatened with several disease states without benefiting the progression of cancer. Even though LMMS failed to improve the survival rate of mice from ovarian cancer, tissue based results in vibrated mice were suggestive for lower tumor incidence that involved fewer organ systems [46], suggesting that LMMS may interfere with the initiation but not the progression of cancer. In order to improve the preventive and/or inhibitory potential of LMMS, perhaps the signal is required to be optimized for bouts, amplitude and frequency based on tissue and/or cancer type.

Our results suggested that mechanical loads have a direct effect on the growth of cancer cells however the hypothesis that mechanical regulation on cancer cells would be obstructed by the physical compliance of these cells requires further testing. Increased compliance is a hallmark of cancer types of various tissues including breast [47], bladder [48], leukemia [49], ovarian [50], gastrointestinal [51] and lung [52] cancers. Cancer cells that show the highest potential for invasion are the cells with the highest compliance [27]. Metastatic capacity is also inversely related to the adhesion strength as metastatic cells lose adhesive properties to the extracellular matrix [53]. Altered physical properties of whole cancer cells therefore should be permissive towards under- or un-loading from the physical loads that are omnipresent in tissues. Consistent with the hypothesis that cancer cells are exposed to 
reduced mechanical loads, highly metastatic cells were shown to have reduced force interactions with each other and their environment [54]. As mechanical forces influence numerous functions in cells [55], the ability of cancer cells to mitigate this influence may affect their survival, proliferation and invasion.

Though we hypothesized a direct link between mechanical loads and cancer cell proliferation, other factors need to be addressed that may compliment or solely dominate the relationship between exercise and cancer. For example, exercise decreases adipose mass, a tissue that can store carcinogens [56-59] and therefore increase the risk for cancer. Further, fat mass is a determinant of fertility, which presents another risk factor for cancer in females [60]. Exercise also lowers circulating levels of insulin, which may act as a growth factor that enhance cell proliferation and inhibit cell death $[61,62]$. Lastly, exercise augments immune function [63,64], which may in turn increase an organism's capability to determine and kill cancerous cells. Direct involvement of mechanical loads in determining the fate of cancer cells may act in tandem with the anti-carcinogenic repertoire that mechanical loads can foster.

\section{Conclusion}

This study serves as a proof-of-principle that regular application of brief daily mechanical stimulus negatively affects the uncontrolled growth of aggressive type breast cancer cells in vitro. Although the mechanisms pertaining to this interaction remains largely elusive, follow up studies warrant further attention to regulation of molecular mechanisms in cancer cells by mechanical loads. If indeed mechanical loading of cancer cells by oscillatory motions is effective in reducing the growth of cancer, this non-invasive approach may be utilized alone or complementary with other therapies to combat against different types of cancer in clinic.

\section{Abbreviations \\ LMMS: Low magnitude mechanical stimulus; FBS: Fetal bovine serum; g: gravity; MTT: (3-(4,5-dimethylthiazol-2-yl)-2,5-diphenyltetrazolium bromide; DMEM: Dulbecco's modified eagle medium; PI: Propidium iodide; DMSO: Dimethyl sulfoxide; PBS: Phosphate-buffered saline; EtOH: Ethanol.}

\section{Competing interest}

The authors declare that they have no competing interests.

\section{Authors' contributions}

Conceived and designed the experiments: EO. Performed the experiments: $\mathrm{MO}$. Analyzed the data: MO and EO. Wrote the paper: MO and EO. Both authors read and approved the final manuscript.

\section{Acknowledgements}

Financial support by The Scientific and Technological Research Council of Turkey (111T577 and 111M604) is gratefully acknowledged. Expert technical help from Drs. Ozden Yalcin-Ozuysal, Esra Erdal and Izmir Institute of Technology, Biotechnology and Bioengineering Research and Application Center is much appreciated.
Received: 15 January 2014 Accepted: 29 September 2014

Published online: 14 October 2014

\section{References}

1. Hanahan D, Weinberg RA: Hallmarks of cancer: the next generation. Cell 2011, 144(5):646-674

2. Schaake W, de Groot $M$, Krijnen WP, Langendijk JA, van den Bergh AC: Quality of life among prostate cancer patients: A prospective longitudinal population-based study. Radiother Oncol 2013, 7(13):00320-00324.

3. Redig AJ, McAllister SS: Breast cancer as a systemic disease: a view of metastasis. J Intern Med 2013, 274(2):113-126.

4. Yang TJ, Ho AY: Radiation therapy in the management of breast cancer. Surg Clin North Am 2013, 93(2):455-471.

5. Wefel JS, Schagen SB: Chemotherapy-related cognitive dysfunction. Curr Neurol Neurosci Rep 2012, 12(3):267-275.

6. Anand P, Kunnumakkara AB, Sundaram C, Harikumar KB, Tharakan ST, Lai OS, Sung B, Aggarwal BB: Cancer is a preventable disease that requires major lifestyle changes. Pharm Res 2008, 25(9):2097-2116.

7. Inoue M: Impact of lifestyle on overall cancer risk among Japanese: the Japan Public Health Center-based Prospective Study (JPHC Study). J Epidemiol 2010, 20(2):90-96.

8. Lee CD, Sui X, Hooker SP, Hebert JR, Blair SN: Combined impact of lifestyle factors on cancer mortality in men. Ann Epidemiol 2011, 21(10):749-754.

9. Westerlind KC: Physical activity and cancer prevention-mechanisms. Med Sci Sports Exerc 2003, 35(11):1834-1840.

10. Centers for Disease Control: The benefits of physical activity. Available online at: www.cdc.gov/physicalactivity/everyone/health/index.html.

11. National Cancer Institute: Physical activity and cancer. Available online at: http://www.cancer.gov/cancertopics/factsheet/prevention/physicalactivity.

12. Friedenreich $C M$, Orenstein MR: Physical activity and cancer prevention: etiologic evidence and biological mechanisms. J Nutr 2002, 132(11 Suppl):3456S-3464S

13. Moorman PG, Jones LW, Akushevich L, Schildkraut JM: Recreational physical activity and ovarian cancer risk and survival. Ann Epidemiol 2011, 21(3):178-187

14. Tse JM, Cheng G, Tyrrell JA, Wilcox-Adelman SA, Boucher Y, Jain RK, Munn LL: Mechanical compression drives cancer cells toward invasive phenotype. Proc Natl Acad Sci U S A 2012, 109(3):911-916.

15. Mierke $C T$, Bretz N, Altevogt $P$ : Contractile forces contribute to increased glycosylphosphatidylinositol-anchored receptor CD24-facilitated cancer cell invasion. J Biol Chem 2011, 286(40):34858-34871.

16. Mierke $C T$, Frey B, Fellner M, Herrmann M, Fabry B: Integrin alpha5beta1 facilitates cancer cell invasion through enhanced contractile forces. J Cell Sci 2011, 124(Pt 3):369-383

17. Orr AW, Helmke BP, Blackman BR, Schwartz MA: Mechanisms of mechanotransduction. Dev Cell 2006, 10(1):11-20.

18. Hahn C, Schwartz MA: Mechanotransduction in vascular physiology and atherogenesis. Nat Rev Mol Cell Biol 2009, 10(1):53-62.

19. Yashiro K, Shiratori H, Hamada H: Haemodynamics determined by a genetic programme govern asymmetric development of the aortic arch. Nature 2007, 450(7167):285-288.

20. Adamo L, Naveiras O, Wenzel PL, McKinney-Freeman S, Mack PJ, GraciaSancho J, Suchy-Dicey A, Yoshimoto M, Lensch MW, Yoder MC, GarcíaCardeña G, Daley GQ: Biomechanical forces promote embryonic haematopoiesis. Nature 2009, 459(7250):1131-1135.

21. Snow-Harter C, Bouxsein ML, Lewis BT, Carter DR, Marcus R: Effects of resistance and endurance exercise on bone mineral status of young women: a randomized exercise intervention trial. J Bone Miner Res 1992, 7(7):761-769.

22. Fuchs RK, Bauer JJ, Snow CM: Jumping improves hip and lumbar spine bone mass in prepubescent children: a randomized controlled trial. J Bone Miner Res 2001, 16(1):148-156.

23. Rubin C, Turner AS, Bain S, Mallinckrodt C, McLeod K: Anabolism: Low mechanical signals strengthen long bones. Nature 2001, 412(6847):603-604

24. Ozcivici E, Luu YK, Adler B, Qin YX, Rubin J, Judex S, Rubin CT: Mechanical signals as anabolic agents in bone. Nature Rev Rheum 2010, 6(1):50-59.

25. Huang S, Ingber DE: Cell tension, matrix mechanics, and cancer development. Cancer Cell 2005, 8(3):175-176.

26. Suresh S: Biomechanics and biophysics of cancer cells. Acta Biomater 2007, 3(4):413-438 
27. Swaminathan V, Mythreye K, O'Brien ET, Berchuck A, Blobe GC, Superfine R: Mechanical stiffness grades metastatic potential in patient tumor cells and in cancer cell lines. Cancer Res 2011, 71(15):5075-5080.

28. Cyrta J, Andreiuolo F, Azoulay S, Balleyguier C, Bourgier C, Mazouni C, Mathieu MC, Delaloge S, Vielh P: Pure and mixed mucinous carcinoma of the breast: fine needle aspiration cytology findings and review of the literature. Cytopathology 2013, 24(6):377-384.

29. Plodinec M, Loparic M, Monnier CA, Obermann EC, Zanetti-Dallenbach $\mathrm{R}$, Oertle P, Hyotyla JT, Aebi U, Bentires-Alj M, Lim RY, Schoenenberger CA: The nanomechanical signature of breast cancer. Nat Nanotechnol 2012, 7(11):757-765

30. Bush JL, Wilson JB, Vail TP: Management of bone loss in revision total knee arthroplasty. Clin Orthop Relat Res 2006, 452:186-192.

31. Cristofolini L: A critical analysis of stress shielding evaluation of hip prostheses. Crit Rev Biomed Eng 1997, 25(4-5):409-483.

32. Friedl $P$, Alexander S: Cancer invasion and the microenvironment: plasticity and reciprocity. Cell 2011, 147(5):992-1009.

33. Koch TM, Munster S, Bonakdar N, Butler JP, Fabry B: 3D Traction forces in cancer cell invasion. PLoS One 2012, 7(3):e33476.

34. Judex S, Lei $X$, Han D, Rubin C: Low-magnitude mechanical signals that stimulate bone formation in the ovariectomized rat are dependent on the applied frequency but not on the strain magnitude. J Biomech 2007, 40(6):1333-1339.

35. Garman R, Rubin C, Judex S: Small oscillatory accelerations, independent of matrix deformations, increase osteoblast activity and enhance bone morphology. PloS ONE 2007, 2(7):e653.

36. Ozcivici E, Garman R, Judex S: High-frequency oscillatory motions enhance the simulated mechanical properties of non-weight bearing trabecular bone. J Biomech 2007, 40(15):3404-3411.

37. Demiray L, Ozcivici E: Bone marrow stem cells adapt to low magnitude vibrations by altering their cytoskeleton both during quiescence and osteogenesis. Turk J Biol 2014. in press.

38. Avvisato CL, Yang X, Shah S, Hoxter B, Li W, Gaynor R, Pestell R, Tozeren A, Byers SW: Mechanical force modulates global gene expression and beta-catenin signaling in colon cancer cells. J Cell Sci 2007, 120(Pt 15):2672-2682.

39. Vassy J, Portet S, Beil M, Millot G, Fauvel-Lafeve F, Karniguian A, Gasset G, Irinopoulou T, Calvo F, Rigaut JP, Schoevaert D: The effect of weightlessness on cytoskeleton architecture and proliferation of human breast cancer cell line MCF-7. FASEB J 2001, 15(6):1104-1106.

40. Ozcivici E: Effects of Spaceflight on Cells of Bone Marrow Origin. Turk J Hematol 2013, 30(1):1-7.

41. Infanger M, Kossmehl P, Shakibaei M, Bauer J, Kossmehl-Zorn S, Cogoli A, Curcio F, Oksche A, Wehland M, Kreutz R, Paul M, Grimm D: Simulated weightlessness changes the cytoskeleton and extracellular matrix proteins in papillary thyroid carcinoma cells. Cell Tissue Res 2006, 324(2):267-277.

42. Ozcivici E, Luu YK, Rubin CT, Judex S: Low-level vibrations retain bone marrow's osteogenic potential and augment recovery of trabecular bone during reambulation. PlOS ONE 2010, 5(6):e11178.

43. Rubin CT, Capilla E, Luu YK, Busa B, Crawford H, Nolan DJ, Mittal V, Rosen CJ, Pessin JE, Judex S: Adipogenesis is inhibited by brief, daily exposure to high-frequency, extremely low-magnitude mechanical signals. Proc Natl Acad Sci USA 2007, 104(45):17879-17884.

44. Luu YK, Ozcivici E, Capilla E, Adler B, Chan E, Shroyer K, Rubin J, Judex S, Pessin JE, Rubin CT: Development of diet-induced fatty liver disease in the aging mouse is suppressed by brief daily exposure to lowmagnitude mechanical signals. Int J Obes(Lond) 2010, 34(2):401-405.

45. Chan ME, Adler BJ, Green DE, Rubin CT: Bone structure and B-cel populations, crippled by obesity, are partially rescued by brief daily exposure to low-magnitude mechanical signals. FASEB J 2012, 26(12):4855-4863.

46. Pagnotti GM, Adler BJ, Green DE, Chan ME, Frechette DM, Shroyer KR, Beamer WG, Rubin J, Rubin CT: Low magnitude mechanical signals mitigate osteopenia without compromising longevity in an aged murine model of spontaneous granulosa cell ovarian cancer. Bone 2012 51(3):570-577

47. Guck J, Schinkinger S, Lincoln B, Wottawah F, Ebert S, Romeyke M, Lenz D, Erickson HM, Ananthakrishnan R, Mitchell D, Käs J, Ulvick S, Bilby C: Optical deformability as an inherent cell marker for testing malignant transformation and metastatic competence. Biophys J 2005, 88(5):3689-3698.
48. Lekka M, Laidler P, Gil D, Lekki J, Stachura Z, Hrynkiewicz AZ: Elasticity of normal and cancerous human bladder cells studied by scanning force microscopy. EurBiophysJ 1999, 28(4):312-316.

49. Chen K, Li D, Jiang YH, Yao WJ, Wang XJ, Wei XC, Gao J, Xie LD, Yan ZY, Wen ZY, Chien S: Influence of expressed TRAIL on biophysical properties of the human leukemic cell line Jurkat. Cell Res 2004, 14(2):161-168.

50. Xu W, Mezencev R, Kim B, Wang L, McDonald J, Sulchek T: Cell stiffness is a biomarker of the metastatic potential of ovarian cancer cells. PLoS One 2012, 7(10):e46609

51. Suresh S, Spatz J, Mills JP, Micoulet A, Dao M, Lim CT, Beil M, Seufferlein T: Connections between single-cell biomechanics and human disease states: gastrointestinal cancer and malaria. Acta Biomater 2005, 1(1):15-30.

52. Cross SE, Jin YS, Rao J, Gimzewski JK: Nanomechanical analysis of cells from cancer patients. Nat Nanotechnol 2007, 2(12):780-783.

53. Indra I, Undyala V, Kandow C, Thirumurthi U, Dembo M, Beningo KA An in vitro correlation of mechanical forces and metastatic capacity. Phys Biol 2011, 8(1):015015.

54. Tambe DT, Hardin CC, Angelini TE, Rajendran K, Park CY, Serra-Picamal X, Zhou EH, Zaman MH, Butler JP, Weitz DA, Fredberg JJ, Trepat X: Collective cell guidance by cooperative intercellular forces. Nat Mater 2011, 10(6):469-475.

55. Hoffman BD, Grashoff C, Schwartz MA: Dynamic molecular processes mediate cellular mechanotransduction. Nature 2011, 475(7356):316-323.

56. Brown KA, Simpson ER: Obesity and breast cancer: mechanisms and therapeutic implications. Front Biosci (Elite edition) 2012, 4:2515-2524.

57. Wang YY, Lehuede C, Laurent V, Dirat B, Dauvillier S, Bochet L, Le Gonidec S, Escourrou G, Valet $P$, Muller C: Adipose tissue and breast epithelial cells: a dangerous dynamic duo in breast cancer. Cancer Lett 2012, 324(2):142-151.

58. Zhao M, Sachs PC, Wang X, Dumur Cl, Idowu MO, Robila V, Francis MP, Ware J, Beckman M, Rizki A, Holt SE, Elmore LW: Mesenchymal stem cells in mammary adipose tissue stimulate progression of breast cancer resembling the basal-type. Cancer Biol Ther 2012, 13(9):782-792.

59. Denham J, Marques FZ, O'Brien BJ, Charchar FJ: Exercise: Putting Action into Our Epigenome. Sports Med 2014, 44(2):189-209.

60. Frisch RE: Body fat, menarche, fitness and fertility. Hum Reprod 1987, 2(6):521-533.

61. Marliss EB, Vranic M: Intense exercise has unique effects on both insulin release and its roles in glucoregulation: implications for diabetes. Diabetes 2002, 51(Suppl 1):S271-S283.

62. Cononie CC, Goldberg AP, Rogus E, Hagberg JM: Seven consecutive days of exercise lowers plasma insulin responses to an oral glucose challenge in sedentary elderly. J Am Geriatr Soc 1994, 42(4):394-398.

63. Morgado JM, Rama L, Silva I, de Jesus Inacio M, Henriques A, Laranjeira $P$, Pedreiro S, Rosado F, Alves F, Gleeson M, Pais ML, Paiva A, Teixeira AM: Cytokine production by monocytes, neutrophils, and dendritic cells is hampered by long-term intensive training in elite swimmers. Eur J Appl Physiol 2012, 112(2):471-482.

64. Gleeson M, Williams C: Intense exercise training and immune function. Nestle Nutr Inst Workshop Series 2013, 76:39-50.

doi:10.1186/s12935-014-0102-z

Cite this article as: Olcum and Ozcivici: Daily application of low magnitude mechanical stimulus inhibits the growth of MDA-MB-231 breast cancer cells in vitro. Cancer Cell International 2014 14:102.

\section{Submit your next manuscript to BioMed Central and take full advantage of:}

- Convenient online submission

- Thorough peer review

- No space constraints or color figure charges

- Immediate publication on acceptance

- Inclusion in PubMed, CAS, Scopus and Google Scholar

- Research which is freely available for redistribution 